\title{
Motivation in Cultural Tourism: The Case of the Traditional and Regional Food Products of West Pomerania
}

\begin{abstract}
In this article, I analyze the factors influencing the motivation of tourists for purchasing regional and traditional products, which are a significant element of the tourist culture of a given region. According to a poll, tourists visiting West Pomerania are interested in such products, although their knowledge of local specialties is limited. The market is characterized by an increasing demand for local products related to local traditions and culture.
\end{abstract}

Słowa kluczowe: motywacja, turystyka kulturowa, region, produkt tradycyjny i regionalny

Keywords: motivation, cultural tourism, region, regional and traditional products

\section{Introduction}

The motivation behind tourist journeys is an important factor associated with satisfying human needs connected with leisure and recreation. Cultural tourism has enormous educational and cognitive potential and, therefore, there are more and more tourists coming to certain regions, including of West Pomerania. This is a region where traditions of various cultures brought by settlers, who came here after the Second World War from remote parts of the country, melt together. With time, 
different recipes and culinary customs of the settlers have become components of the West Pomeranian tradition, creating new and different cultural norms. Regional and traditional food products combined with elements of the regional culture determine a region's autonomy and the devotion of its inhabitants to tradition. In turn, tourists' needs determine the tourist-recreational activity of the population and influence their preferences, affecting the choices made by consumers according to their knowledge, social status and financial means. The subject matter of presented analyses are the factors motivating consumers to choose traditional and regional foodstuffs and, consequently, to learn about the culture of the region they are produced in. This paper attempts to extend the knowledge about how tourists' motivation influences choices of regional and traditional products made by them during their stay in West Pomerania and about the actions to be taken in order to increase the interest in such products.

\section{A concept of motivation and its role in the aspect of satisfying human needs}

The activity of humans is closely related to the satisfying of needs. Needs, referred to as "desires based on subjective feelings and awareness" [Sztaba 2007: 369], are the source of motivation behind human actions. Motivation processes depend on different needs and they determine particular consumer behavior. Each experience which spurs a human to action (...) and facilitates or hampers its completion [Gracz, Sankowski 2001: 117] can be referred to as a motive. The motive sets a course of action taken to reach a certain goal. Needs create a general tendency for implementation, whereas motives define and set specific actions [Niezgoda 1999: 37, cit. per: Jędrysiak 2008: 20]. Generally, there are a number of separate motives driving the human activity. This is a characteristic feature of the human behavior called "polymotivativeness." The word "motivation" is a derivative of Latin motus meaning "spurred or stimulated." It is a psychological mechanism producing "a reaction to the lack of satisfying certain psychic or biological needs that decide choices and actions" [Sztaba 2007: 282]. The actions result from the physiology of a human body, social nature of human behavior and cultural standards of regions. From the psychological point of view the motivation is used for describing all mechanisms responsible for commencing, shaping, maintaining and ending the behavior [Łukaszewski 2000: 427]. Issues of motivation are considered within the framework of numerous domains, in particular psychology and economic sciences, as well as in disciplines dealing with organization and management [Sekuła 2008: 10]. From the economic point of view the motivation for taking a certain action depends on the usability, satisfaction derived from consuming goods and services and its value for an individual, and probability of reaching the goal [Zdebski 1996: 84]. The motivation process can also be considered in terms of exact science, such as mathematics, and be defined as 
a function of expecting certain behaviors and activities through which the set goal can be achieved [James et al. 2008: 10]. Motivating is also a function of management, one of the most important elements of managing human resources. There are many motivation concepts and theories, and the following are particularly noteworthy:

- theory of content, including Maslow's theory of needs, Herzberg's theory of motivation, Atkinson's theory of achievement motivation, McClelland's theory of needs, McGregor's theory of work;

- theory of process, including Vroom's expectancy theory, drive reduction theory (the well-known motivation theory pioneered by J. Bentham and J.S. Mill, the author of contemporary drive reduction theory is C.L. Hull);

- Skinner's theory of performance excellence, closely associated with the theory of behavior modification or theory of learning [Hofstede et al. 2011: 333].

The most widely recognized and practically useful concept of needs is the theory of needs developed by Abraham Maslow, who divided needs into five main categories and noticed the human motivation in each of them. He identified physiological needs, safety needs, social needs, esteem needs and self-actualization needs. Maslow stated that individuals must satisfy lower level needs (more important ones, i.e. physiological and safety needs) before progressing on to meet higher level needs that are slightly less important [Maslow 1994 (1954): 80]. The more specific attempt would lead to the identification of two highest groups, such as cognitive needs and aesthetic needs. The research, however, shows the hierarchy developed by Maslow is not universal and identical for everyone. It may differ depending on the cultural environment individuals live in, as well as on economic or geographical conditions, among other things. Maslow's theory of the hierarchy of needs can be applied to the motivation process for the analysis and assessment of satisfying the needs from certain tiers of the pyramid with regard to expectations of a work team or group of tourists. It gives a chance of a quick response in case of finding insufficient motivation within a certain group. It should be noted that the self-actualization need, of the fifth and highest tier of the pyramid, is personalized and exclusively depends on the individual preferences of a given person. Thus, conditions for self-actualization should not be provided without making sure the direction meets personal preferences of an individual.

\section{Sources and classification of tourist motivation}

The motivation as a state of readiness to take certain actions connected with satisfying human needs is one of the key non-economic factors stimulating the growth in tourism [Gaworecki 2003: 138]. Sources of the tourist motivation can be both internal resulting from a system of the human needs, and external [Gołembski 2009: 67]. Tourism is generally considered to be a need of a higher tier and is found on higher 
levels of Maslow's pyramid of needs. In case of increased prices of goods and services (e.g. due to inflation, wealth decline or any other events decreasing the feeling of safety) consumers who considered tourism to be a basic need, change their preferences and tend to satisfy the needs from lower levels of the pyramid [Łazarek 2001: 27].

The motivation for tourist activities emerges after satisfying the first level needs, provided individuals have sufficient resources that could be spent on leisure and recreation. Tourist needs are material and spiritual, and concern goods and services of the higher tier and luxury goods. They are continually transformed and modified through learning processes and social development [Winiarski, Zdebski 2008: 46]. Tourist needs are connected with different actions taken during free time with regard to, for instance, tourist and recreation activities [Siwiński 2010: 81]. A basis for the motivation for tourist journeys in contemporary humans is also a group of other factors connected with the transportation accessibility to a visited location, social pressure, acceptance to follow the social customs or attempts to join a chosen social group. The structure of the tourist motivation covers three groups of motives: social motives, family and tribal motives, and personal and selfish motives [Gaworecki 2003: 139]. The motivation is an essential issue of the tourist activity and the fulfilment of needs has become a basis for the classification of travel motives. The literature provides many proposals concerning the classification of travel motives. An idea developed by Victor T.C. Middleton is one of the most frequently quoted, and the author identified six key groups of tourism participation motives [Middleton 1996: 54-55], these are: (1) cultural, psychological, educational motives; (2) physiological and physical culture-related motives; (3) social and ethnic motives; (4) ludic motives related to amusement and entertainment; (5) religious motives; (6) motives connected with work. A need for traveling may originate from a natural curiosity of the world and need for exploration, as well as from the innate tendency to change the surroundings. In the contemporary society, however, the imitation ritual strengthened by more and more intense growth in the tourist industry has become the civilization standard [Winiarski, Zdebski 2008: 51].

Human behavior is driven by lots of motives and the assessment and analysis of them make it possible to learn about behavioral models. It is difficult though to explicitly state how the needs emerge, how motives can be stimulated and controlled, finally, why consumers of tourist goods and services demonstrate certain purchase preferences [Rudnicki 2010: 49-50]. 


\section{Culture tourism in the region}

Culture tourism is one of the most important segments of tourism which is based on contacting local communities and learning about their culture. It is a complex and multidimensional phenomenon. It is associated with education and cognitive journeys, the key motive of them being exploration of areas and facilities of historic and artistic value, as well as participation in cultural events.

One of the most significant offers of Polish culture tourism is regional culture, which is an enclave of authenticity. The idea of culture tourism is most completely expressed in the following definition: Culture tourism is an activity of persons undertaken in a place of their tourist stay which enables learning about the way of living of other individuals, cultural heritage, social customs, cuisine, folklore and religious traditions.

Culture tourism is a form of visiting native populations that cultivate a traditional way of living and keep local tradition alive. The growth of this kind of tourism entails economic and cultural benefits for both groups - tourists and native communities. Thus, tolerance and mutual understanding develop between two communities - those generating and those receiving tourists.

The growth in culture tourism in EU countries stimulates the development of the tourist industry and is one of economic and social priorities, whereas tourism is regarded as a function, element, and message of the culture and a factor of its change [Panasiuk 2006: 36]. Culture tourism is a form of cognitive tourism that can be divided as follows:

a) intellectual culture tourism (museum tourism, cultural heritage tourism);

b) education tourism (study, specialist, language seminar journeys);

c) general culture tourism (urban, ethnic, military, industrial, exotic, culinary, regional, pilgrimage tourism) [von Rohrscheidt 2008: 51].

It is also essential to identify tourist attractions that are landmarks in a certain area, and their existence is a main criterion for choosing locations and places and attaching their importance to tourism [Kruczek 2004: 90] (Figure 1).

One of the key elements in the above classification is gastronomy, which covers ideas related to traditional and regional foodstuffs. The cultural heritage is inseparably connected with the social-economic growth, culture and adopted system of values pursued by the society in a given phase of development.

The cultural landscape of a region is subject to the continuous evolution. New trends in architecture emerge, the way of living and interests of the community change, new folklore characteristic for the region develops. The growth in culture tourism results from human needs and behavior based on the interest in a region's cultural heritage. In West Pomerania there are many tourist attractions - including buildings, palaces and parks, museums, churches and chapels, defensive walls, rural buildings - that can easily be converted to serve tourist activity purposes. 

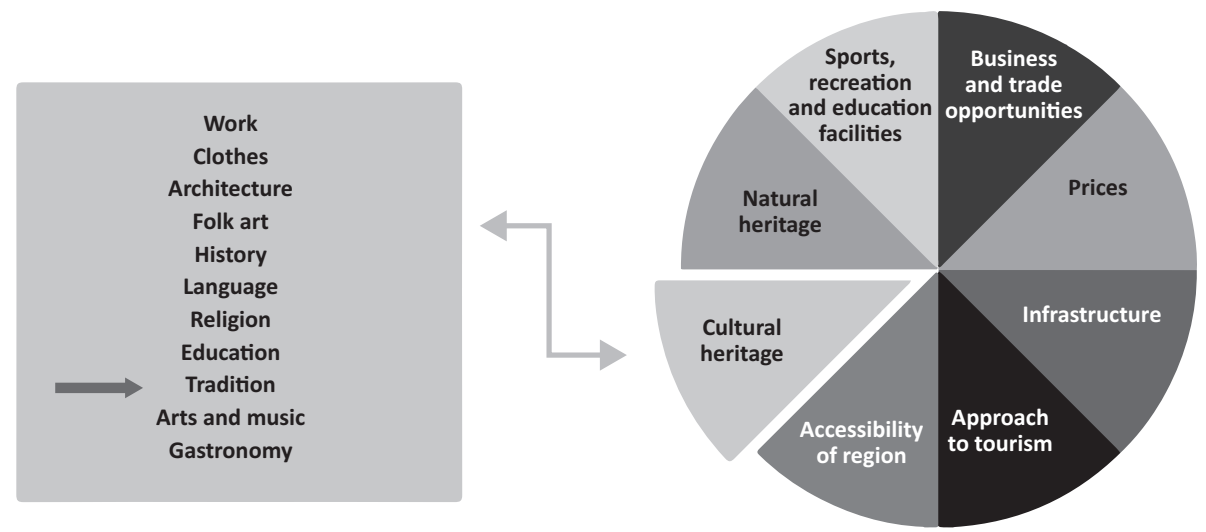

Figure 1. Types of tourist attractions according to J.R. Brent Ritchie, M. Zins (1978)

Source: author's study on the basis of Jędrysiak [2008, pp. 14-15] after Kruczek [2004, p. 90].

Furthermore, monuments of old engineering, such as lighthouses, harbor facilities, mills and hydroelectric power plants and military monuments are found in the region.

Charming landscape roads, forest facilities and leisure and education paths can contribute to tourism development. The distinctness of the region in terms of economy and culture was developed by vicissitudes of communities that had inhabited the region. Following socio-economic changes of the 1990s, West Pomerania extends its offer of tourist services along with the farming activities and attracts tourists with peace, silence, climate and regional cuisine. Various folklore events, fairs, music festivals and sports events are organized to promote rural tourism. The most important cultural events include St. James Fair in Szczecin, Festival of Organ and Chamber Music in Kamień Pomorski and Koszalin, Festival of Vikings in Wolin, Fair of Agriculture in Barzkowice, Days of the Sea in Szczecin, and fests where regional foods are served and folk customs are presented in many different communes throughout the province.

The rural tourism, agritourism, and ecotourism complement the region's tourist offer. Organizers and operators of rural tourism can extend their offer to include culture tourism. More and more often tourists become interested in rural culture and are willing to combine their holiday stay with learning about folklore, history of monuments, legends and tradition. Moreover, tourists begin to enjoy resting far from the noise of popular and famous health resorts. Culture is a valuable asset to the rural tourism as it enriches the offer for visitors who would take advantage of attractions of holiday on farms [Matlegiewicz 2011: 65-75]. 


\section{Traditional and regional foodstuffs as a component of a region's culture}

Traditional and regional products emphasize the distinctiveness and cultural differentiation, and they form a part of history concerning the emerging and development of region's material culture. Due to its diversity and specific features of meals and food products of the region, culinary traditions play a significant role in promoting the region.

Research proves that $15 \%$ of all tourists are exclusively interested in the genuine, traditional or regional cuisine. The culinary art of the region was significantly influenced by customs connected with religion, contact with other cultural circles, as well as by local geographical and socio-economic conditions [Jędrysiak 2008: 90].

The attractiveness of regional and traditional products depends upon their strong identificationwith the region, typical recipes and use of local ingredients, which distinguishes them from the ones coming from other parts of the country. West Pomerania is not only a region with rich and turbulent history, but also of exceptional traditions, customs and culture. Newcomers and settlers brought different recipes and culinary traditions here. Some of them fitted with the old tastes of the pre-war time. Due to processes that occurred, meals and products create an unique culinary climate of West Pomerania.

The promotion and sale of traditionally produced foods may contribute to new jobs, thus increasing the number of income sources. Consumers are becoming interested in and recognize traditional and regional foodstuffs contributing to the strengthening of the regional identity. In response to needs and expectations of the consumers the region offers an ever increasing number of traditional products made from natural raw materials and following traditional preparation values not found in the factory made equivalent [Matlegiewicz 2011: 65-75].

In Poland products of the traditional nature and those made in a traditional way can be entered into the Traditional Products List (TPL) kept by the Marshall of the Region, and the list contains information on regional Polish cuisine and Polish tradition, production methods and their specific features [Ministry of Agriculture and Rural Development 2010]. A product found on the TPL proves its uniqueness since it meets requirements set forth in the "Act on the registration and protection of names and marking of regional products and foodstuffs and traditional products of 2004" (“Journal of Laws" 2005, Vol. 10, item 68, as amended). Farming products, foodstuffs and spirits can be entered into the TPL after having met the following conditions:

- quality of products or their exceptional properties and features result from the application of traditional production methods used for 25 years;

- products are part of the cultural heritage of a region in which they are made;

- products are elements of the local social identity [Ministry of Agriculture and Rural Development 2010]. 
The entry into the TPL does not assure the product protection or the control of production compliance according to a declared production process.

In Poland there are ten product categories of entry into the TPL [Ministry of Agriculture and Rural Development 2012]. They are as follows: dairy products, meats, fish products, fruits and vegetables, pastry and confectionary, oils and fats, mead, ready-made meals and dishes, beverages, other products.

Table 1 shows the number of traditional products, arranged by Poland's provinces, in the years 2005-2019.

Table 1. Traditional products by Poland's provinces in years: 2005, 2008, 2012, 2015 and 2019

\begin{tabular}{|c|c|c|c|c|c|c|c|c|c|c|c|}
\hline \multirow{3}{*}{ Province } & \multirow{2}{*}{\multicolumn{5}{|c|}{$\begin{array}{c}\text { Number of registered } \\
\text { traditional products }\end{array}$}} & \multirow{3}{*}{ Province } & \multicolumn{5}{|c|}{$\begin{array}{l}\text { Number of registered } \\
\text { traditional products }\end{array}$} \\
\hline & & & & & & & \multicolumn{5}{|c|}{ Year } \\
\hline & 2005 & 2008 & 2012 & 2015 & 2019 & & 2005 & 2008 & 2012 & 2015 & 2019 \\
\hline Lower Silesian & 1 & 6 & 35 & 44 & 49 & Subcarpathian & 7 & 11 & 111 & 180 & 229 \\
\hline $\begin{array}{l}\text { Kuyavian- } \\
\text {-Pomeranian } \\
\end{array}$ & 0 & 6 & 39 & 57 & 86 & Podlaskie & 16 & 1 & 45 & 59 & 70 \\
\hline Lublin & 15 & 9 & 98 & 134 & 210 & Pomeranian & 0 & 19 & 134 & 160 & 178 \\
\hline Lubusz & 0 & 0 & 13 & 39 & 78 & Silesian & 0 & 23 & 130 & 137 & 145 \\
\hline Łódź & 0 & 15 & 67 & 84 & 141 & Holy Cross & 0 & 2 & 54 & 70 & 92 \\
\hline Lesser Poland & 11 & 3 & 58 & 139 & 218 & $\begin{array}{l}\text { Warmian- } \\
\text {-Masurian }\end{array}$ & 0 & 13 & 24 & 25 & 34 \\
\hline Masovian & 0 & 3 & 49 & 76 & 139 & Greater Poland & 2 & 6 & 86 & 90 & 93 \\
\hline Opole & 3 & 2 & 52 & 61 & 62 & \begin{tabular}{|l} 
West \\
Pomeranian
\end{tabular} & 0 & 3 & 16 & 32 & 53 \\
\hline \multirow{2}{*}{ Total } & \multicolumn{3}{|c|}{2005} & \multicolumn{2}{|c|}{2008} & 2012 & \multicolumn{3}{|c|}{2015} & \multicolumn{2}{|c|}{2019} \\
\hline & \multicolumn{3}{|c|}{55} & \multicolumn{2}{|c|}{122} & 1011 & \multicolumn{3}{|c|}{1387} & \multicolumn{2}{|c|}{1877} \\
\hline
\end{tabular}

Source: author's study on the basis of materials issued by Ministry of Agriculture and Rural Development, Warsaw 2006, 2010, 2012, www.minrol.gov.pl [accessed: 15.07.2020].

In 2019 in Poland there were 1877 traditional products included in all the categories. In 2019 West Pomerania and Warmian-Masurian province were the ones with the smallest number of regional and traditional products entered into the TPL. The products broken down by categories are shown in Table 2 .

An essential issue of the Common Agricultural Policy is to protect products and delicacies the specific character of which results from the traditional production process as well as from their origin in a geographical region of special climate conditions, specific conditions connected with the history and unique production tradition [Matlegiewicz 2014: 151-166]. The European Union pays much attention to the protection of registered marking under the applicable laws. Upon its accession to the EU, Poland was allowed the possibility of applying for the protection of its products. The process is governed by an act on the registration and 
Table 2. Breakdown of products entered into the TPL, West Pomerania, year 2020

\begin{tabular}{|c|c|c|}
\hline $\begin{array}{l}\text { Pastry and confectionary: } \\
\text { Chleb gwdowski, Chleb razowy } \\
\text { koprzywieński, Chleb szcze- } \\
\text { ciński, Chleb wiejski wojenny, } \\
\text { Choszczeńska strucla z makiem, } \\
\text { Jabłuszka w koszulkach, Krówka } \\
\text { szczecinecka, Paszteciki gwdow- } \\
\text { skie, Pierniki szczecińskie, Serca } \\
\text { kaziukowe }\end{array}$ & $\begin{array}{l}\text { Mead: } \\
\text { Miody leśne z Tuczna Drugiego, } \\
\text { Miody Pojezierza Drawskiego, } \\
\text { Miody ze Wzgórz Świeszewskich, } \\
\text { Akacjowy miód cedyński, Miód } \\
\text { drahimski, Miody dębickie, Miody } \\
\text { Pojezierza Choszczeńskiego, Mio- } \\
\text { dy przelewickie, Miody Puszczy } \\
\text { Barlineckiej, Miody rusionowskie, } \\
\text { Miody wałeckie, Miody z Lasu } \\
\text { Św. Marii }\end{array}$ & \begin{tabular}{l}
\multicolumn{1}{c}{ Beverages: } \\
Zakwas buraczany z Dębna, Miód \\
pitny trójniak Czcibor, Piwo szcze- \\
cińskie, Lipiańskie piwo Zaczynaj, \\
Miód pitny trójniak, Miód pitny \\
trójniak cedyński, Nalewka ze \\
śliwek z Dębiny, Trójniak woliński \\
leśny, Wino ze śliwek
\end{tabular} \\
\hline $\begin{array}{l}\quad \text { Fruits and vegetables: } \\
\text { Powidła radziszewskie, Jeziorowy } \\
\text { ogórek kiszony, Kapusta kiszona } \\
\text { z beczki, Konfitura szczecińska } \\
\text { z owoców róży, Konfitura szcze- } \\
\text { cińska z zielonych pomidorów, } \\
\text { Ogórek kołobrzeski, Ziemniak } \\
\text { wyszoborski }\end{array}$ & \begin{tabular}{l}
\multicolumn{1}{c}{ Fish products: } \\
Miedwieńskie ryby wędzone, \\
Paprykarz szczeciński, Sieja \\
miedwieńska, Sieja wędzona z Po- \\
jezierza Drawskiego, Śledzie po \\
szczecinsku, Śledzik kołobrzeski
\end{tabular} & $\begin{array}{l}\text { Ready-made meals and dishes: } \\
\text { Bełczańskie zupy piwne, Hołubcie } \\
\text { bielkowskie, Kiszka szwedzka, } \\
\text { Pasztecik szczeciński }\end{array}$ \\
\hline $\begin{array}{l}\text { Meats: } \\
\text { Kiełbasa krucha domowa, Pasztet } \\
\text { z gęsi, Szynka świdwińska, Wędzo- } \\
\text { ny udziec wieprzowy z Przelewic }\end{array}$ & $\begin{array}{l}\text { Dairy products: } \\
\text { Ser bałtycki }\end{array}$ & $\begin{array}{c}\text { Other products: } \\
\text { Grzyby marynowane szyszką }\end{array}$ \\
\hline
\end{tabular}

Source: Zachodniopomorski ODR in Barzkowice, www.minrol.gov.pl [accessed: 15.07.2020].

protection of names and markings of farming products and foodstuffs and on traditional products ("Journal of Laws" 2005, Vol. 10, item 68 and 2008, Vol. 171, item 1056 and 2016, item 1368) [Oznaczenie geograficzne, nazwy pochodzenia oraz gwarantowane tradycyjne specjalności w Polsce 2009].

Such processes are accompanied by the protection of culinary and cultural heritage, promotion of the tradition and propagation of tradition all over Europe. Main marks to identify farming products and foodstuffs are as follows:

- products assigned to a certain territory: Protected Designation of Origin (PDoO), Protected Geographical Indication (PGI);

- products referred to certain production methods: Traditional Specialty Guaranteed (TSG) [European Comission, European Policy for Quality of Agricultural Products 2007: 6].

Awarding one out of three EU certificates which are then put on labels means the guarantee of a product origin and official confirmation of the high quality of a product which results from specific regional conditions, history and unique production process. Table 3 lists certificates identifying farming products and foodstuffs.

It should be noted that traditional products, as opposed to the regional ones, are characterized primarily by the traditional composition, recipe, and production method. The regional products on the other hand are identified and determined by their origin. 
Table 3. EU instruments to identify farming products and foodstuffs

\begin{tabular}{|c|l|l|l|}
\hline Item & \multicolumn{1}{|c|}{ Designation } & \multicolumn{1}{|c|}{ Geographical origin of product } & \multicolumn{1}{c|}{ Specific product features } \\
\hline 1 & $\begin{array}{l}\text { Protected } \\
\text { Designation } \\
\text { of Origin }\end{array}$ & $\begin{array}{l}\text { means a name of the product from a cer- } \\
\text { tain region, place, country. Quality and } \\
\text { features of the product result from effect } \\
\text { of geographical environment comprising } \\
\text { both natural and human factors }\end{array}$ & $\begin{array}{l}\text { refers to geographical area where all } \\
\text { phases of production take place }\end{array}$ \\
\hline 2 & $\begin{array}{l}\text { Protected } \\
\text { Geographical } \\
\text { Indication }\end{array}$ & $\begin{array}{l}\text { means a name of the product from } \\
\text { a certain region, place or country, and its } \\
\text { quality, reputation or other features are } \\
\text { effect of given geographical origin }\end{array}$ & $\begin{array}{l}\text { refers to geographical area where at least } \\
\text { one phase of production takes place }\end{array}$ \\
\hline 3 & $\begin{array}{l}\text { Traditional } \\
\text { Specialty } \\
\text { Guaranteed }\end{array}$ & $\begin{array}{l}\text { means a product of a specific feature } \\
\text { that is different from other products } \\
\text { belonging to the same category }\end{array}$ & $\begin{array}{l}\text { refers to specific features of the product; } \\
\text { the product name itself should be } \\
\text { specific }\end{array}$ \\
\hline
\end{tabular}

Source: author's study on the basis of: Oznaczenia geograficzne, nazwy pochodzenia oraz gwarantowane tradycyjne specjalności w Polsce (2009), Ministerstwo Rolnictwa i Rozwoju Wsi, Warszawa: Wydawnictwo Naukowe Instytutu Technologii i Eksploatacji Państwowego Instytutu Badawczego, http://www.minrol.gov.pl, http://www. potrawyregionalne.pl [accessed: 10.07.2020]; Vademecum Ochrony Produktów Regionalnych i Tradycyjnych 2004.

The above classification can be shown in the form of the below diagram (Figure 2).
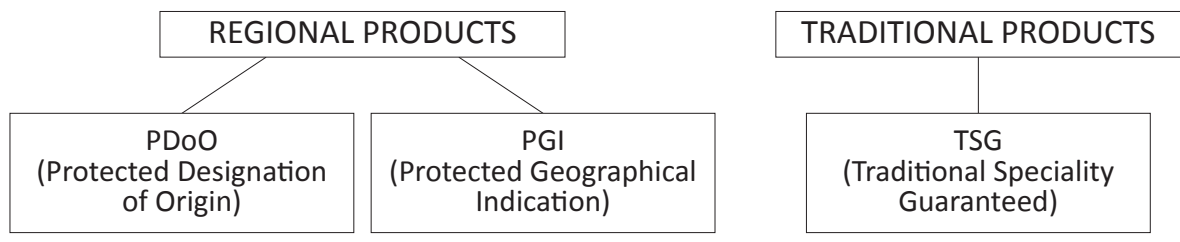

Figure 2. Classification of regional and traditional products

Source: author's study.

A system of the protection of the geographical and traditional indication used in the European Union is one of elements of the protection and promotion of Polish specialties. A product with one of the above mentioned certificates is recognizable on the European market and carries the highest quality, which attracts more buyers. Polish traditional and regional products that are labelled with EU certificates are listed in Table 4.

As shown above, there are 39 Polish products registered with the European system of food quality. Most of them come from the małopolskie province, whereas the wielkopolskie province features the smallest number of the products concerned. West Pomerania has just one product registered as the $\mathrm{PDoO}$, and in four provinces there are no certified products. 
Table 4. Polish traditional and regional products protected within the EU (registered with European system of food quality, year 2020)

\begin{tabular}{|c|c|c|c|}
\hline Province & $\begin{array}{l}\text { Product name registered } \\
\text { as Protected Designation } \\
\text { of Origin }(\mathrm{PDoO})\end{array}$ & $\begin{array}{l}\text { Product name registered } \\
\text { as Protected Geographical } \\
\text { Indication (PGI) }\end{array}$ & $\begin{array}{c}\text { Product name registered } \\
\text { as Traditional Specialty } \\
\text { Guaranteed (TSG) }\end{array}$ \\
\hline Lower Silesian & - & $\begin{array}{l}\text { Miód wrzosowy z Borów } \\
\text { Dolnośląskich }\end{array}$ & - \\
\hline Kuyavian-Pomeranian & - & - & - \\
\hline Lublin & - & Cebularz lubelski & - \\
\hline Lubusz & - & - & - \\
\hline Łódź & - & - & - \\
\hline Lesser Poland & $\begin{array}{l}\text { Bryndza podhalańska, } \\
\text { Oscypek, Redykołka, } \\
\text { Karp zatorski, Fasola } \\
\text { Piękny Jaś z Doliny } \\
\text { Dunajca }\end{array}$ & $\begin{array}{l}\text { Jagnięcina podhalańska, } \\
\text { Suska sechlońska, Kiełbasa } \\
\text { lisiecka, Obwarzanek } \\
\text { krakowski, Jabłka łąckie, } \\
\text { Chleb prądnicki }\end{array}$ & - \\
\hline Masovian & - & $\begin{array}{l}\text { Miód kurpiowski, Jabłka } \\
\text { grójeckie }\end{array}$ & - \\
\hline Opole & - & Kołacz śląski & - \\
\hline Subcarpathian & $\begin{array}{l}\text { Podkarpacki miód spa- } \\
\text { dziowy, Fasola wrzawska }\end{array}$ & - & - \\
\hline Podlaskie & - & Ser koryciński swojski & Pierekaczewnik \\
\hline Pomeranian & - & Truskawka kaszubska & - \\
\hline Silesian & - & Krupniok śląski & - \\
\hline Holy Cross & Wiśnia nadwiślańska & $\begin{array}{l}\text { Fasola korczyńska, Śliwka } \\
\text { szydłowska }\end{array}$ & - \\
\hline Warmian-Masurian & - & - & - \\
\hline Greater Poland & 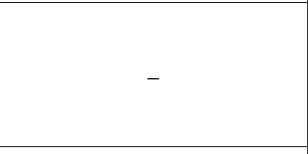 & $\begin{array}{l}\text { Rogal świętomarciński, } \\
\text { Wielkopolski ser smażony, } \\
\text { Andruty kaliskie, Kiełbasa } \\
\text { biała parzona wielkopolska }\end{array}$ & Olej rydzowy \\
\hline West Pomeranian & Miód drahimski & - & - \\
\hline Entire Poland & - & - & $\begin{array}{l}\text { Półtorak, Dwójniak, Trój- } \\
\text { niak, Czwórniak, Kiełba- } \\
\text { sa jałowcowa, Kiełbasa } \\
\text { myśliwska, Kabanosy }\end{array}$ \\
\hline $\begin{array}{l}\text { Cross-boarder applica- } \\
\text { tion from Poland and } \\
\text { Lithuania }\end{array}$ & $\begin{array}{l}\text { Miód ze Sejneńszczyzny / } \\
\text { z Łoździejszczyzny }\end{array}$ & - & - \\
\hline
\end{tabular}

Source: author's study on the basis of: Oznaczenia geograficzne, nazwy pochodzenia oraz gwarantowane tradycyjne specjalności w Polsce (2009), Ministerstwo Rolnictwa i Rozwoju Wsi, Warszawa: Wydawnictwo Naukowe Instytutu Technologii i Eksploatacji Państwowego Instytutu Badawczego, http://www.minrol.gov.pl, http://www. potrawyregionalne.pl [accessed: 10.07.2020]. 


\section{Motivation in culture tourism based on traditional and regional products according to respondents - methodologgy and results}

The research was based on the diagnostic poll conducted by means of questionnaires and carried out by Department of Tourism and Recreation students of the WSB University, during study visits in 2019. The research was done under the supervision of the author on a group of 350 tourists in four cities and towns of West Pomerania, namely, Szczecin, Kołobrzeg, Drawno and Barlinek. Three hundred and twenty-five questionnaires were correctly filled in and taken into consideration with regard to the poll. The research was aimed at the identification and analysis of choice motives concerning traditional and regional foodstuffs and products of West Pomerania in a group of respondents described in Table 5.

Table 5. Specifications of respondents by sex, age, education, place of residence

\begin{tabular}{|l|c|c|c|c|c|c|c|c|c|c|}
\hline \multicolumn{1}{|c|}{ Category } & \multicolumn{3}{|c|}{ Age } & \multicolumn{3}{c|}{ Education } & \multicolumn{2}{c|}{ Sex } & \multicolumn{2}{c|}{$\begin{array}{c}\text { Place } \\
\text { of residence }\end{array}$} \\
\hline Details & $\begin{array}{c}\text { Up to } \\
30 \text { years }\end{array}$ & $\begin{array}{c}30-50 \\
\text { years }\end{array}$ & $\begin{array}{c}\text { Above } \\
50 \text { years }\end{array}$ & Primary & Secondary & Higher & Female & Male & Country & City \\
\hline $\begin{array}{l}\text { No. } \\
\text { of respondents }\end{array}$ & 105 & 172 & 48 & 78 & 132 & 115 & 185 & 140 & 108 & 217 \\
\hline
\end{tabular}

Source: author's study on the basis of questionnaires.

The poll showed that respondents aged $30-50$ years prevailed $(52.9 \%$ of the total). Among them there were more women (185, equivalent to $56.9 \%$ of the total). Most respondents had secondary education (132 persons, $40.6 \%$ of the total) and lived in cities (66.7\%).

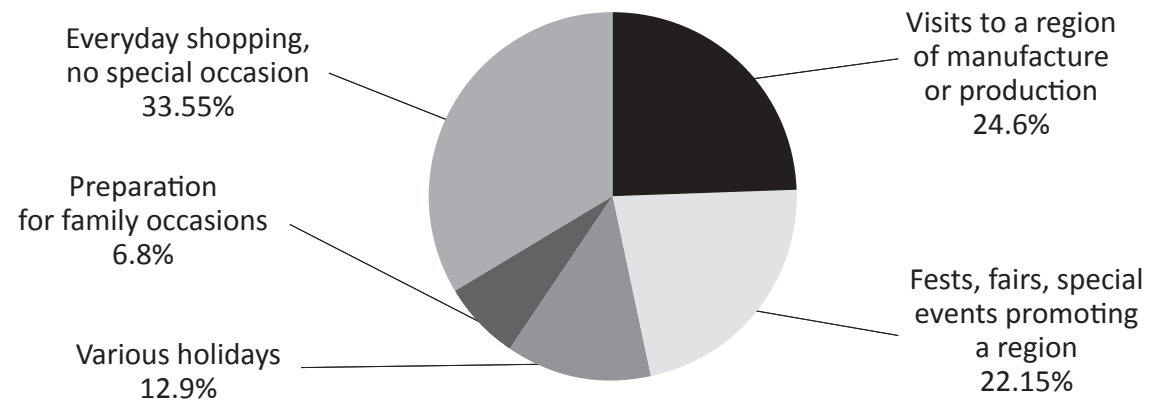

Figure 3. Situations and circumstances of purchase, traditional and regional food

Source: author's study on the basis of research. 
Results depicted in Figure 3 show there was no randomness with regard to choices made by consumers of the traditional food, which is proved by the fact of purchasing such foods without any occasion (109 respondents, $33.55 \%$ of the total). Opportunities for purchasing the food in question, such as access to the food during visits to the region of production and manufacture, facilitated the purchase ( 80 persons, $24.6 \%$ of the total), this was also the case for fests, fairs and promotion events ( 72 persons, $22.15 \%$ of the total).

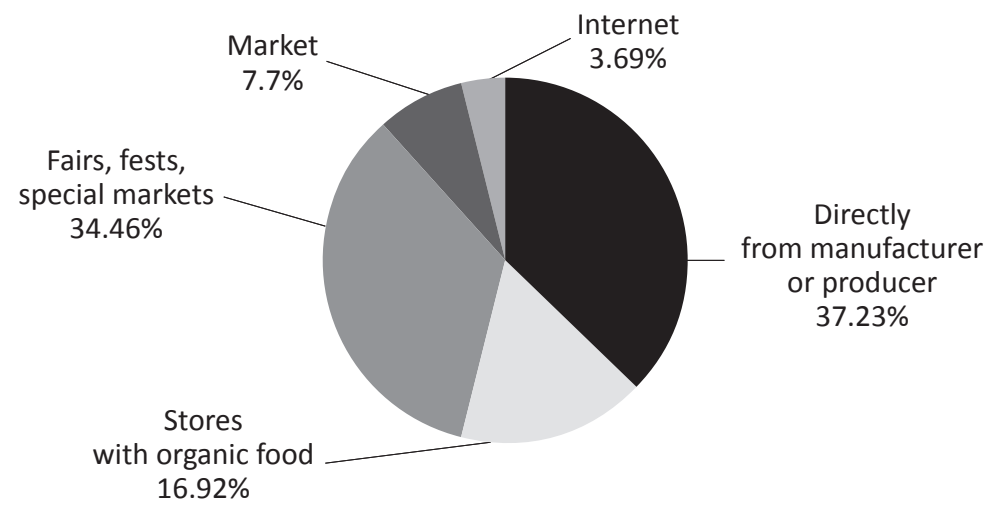

Figure 4. Traditional and regional food - place of purchase

Source: author's study on the basis of research.

The information given in Figure 4 shows that traditional and regional food is most frequently purchased from producers and manufacturers - 121 persons, that is, $37.23 \%$. It seems to be connected with consumer's expectations, compliance with traditional production requirements and recipes and a reputation of the producer. The next important places of purchase are fairs, fests and special markets (112 persons, $34.46 \%$ of the total).

The most frequent motive for purchasing traditional and regional products (Figure 5) was the smell and taste of a product (104 persons, 32\%). The second most important factor was pro-health values (no preservatives, artificial dyes, flavor improvers, etc.), (95 persons, $29.2 \%$ of the total). The distribution of responses shows that the motivation to choose these products by consumers is based on the factors related to perception, such as the perception of tastes or emotions accompanying the cultivation of tradition, or on the collection of new experiences.

The respondents most frequently purchased dairy products $(26.77 \%)$, meats $(29.85 \%)$, pastry and confectionary (28\%) respectively (Figure 6). The variety of products indicated by respondents suggests that traditional and regional food of all kinds is not easily accessible in the mass food market. 


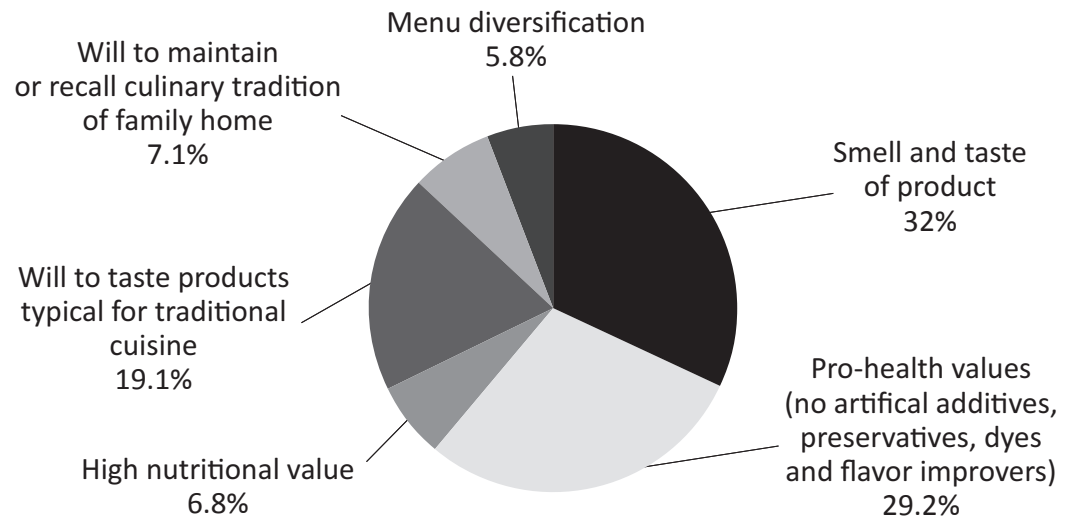

Figure 5. Traditional and regional food, purchase motives

Source: author's study on the basis of research.

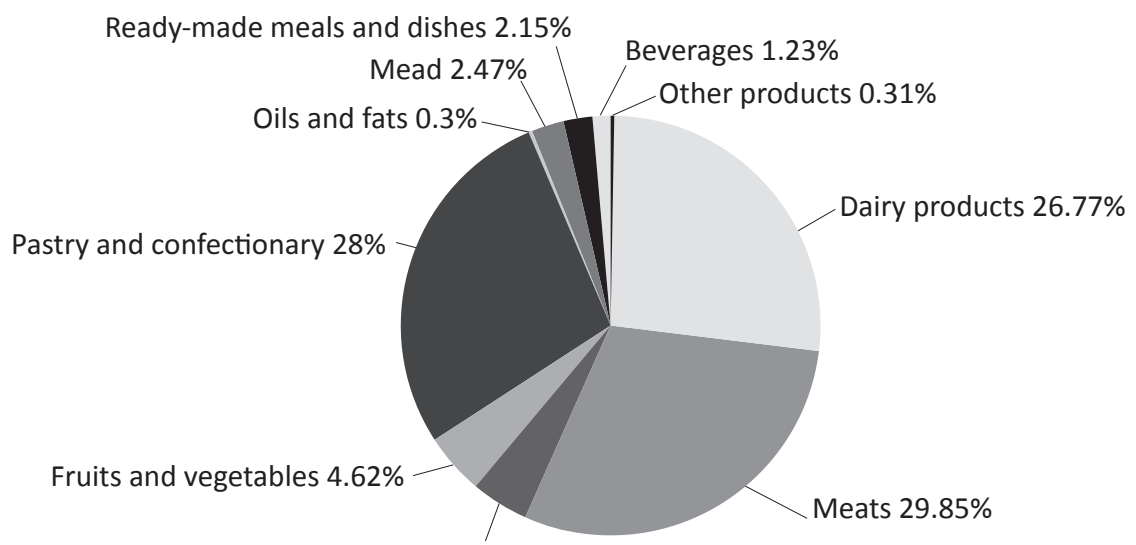

Fish products $4.3 \%$

Figure 6. Most frequently purchased groups of traditional and regional products

Source: author's study on the basis of research.

The research (Figure 7) shows that respondents are generally regular customers purchasing traditional and regional products a few times a month (163 persons, $50.2 \%$ of the total). This proves the constant nature of the needs that determine the motives for choosing this type of products.

The substantial majority of the respondents (239 persons, $73.2 \%$ ) spent up to PLN 350 on the purchase of traditional and regional products (Figure 8).

According to the respondents (Figure 9) the higher sales and growth in consumption could be influenced by lower prices (129 persons, 39.7\%), the second 


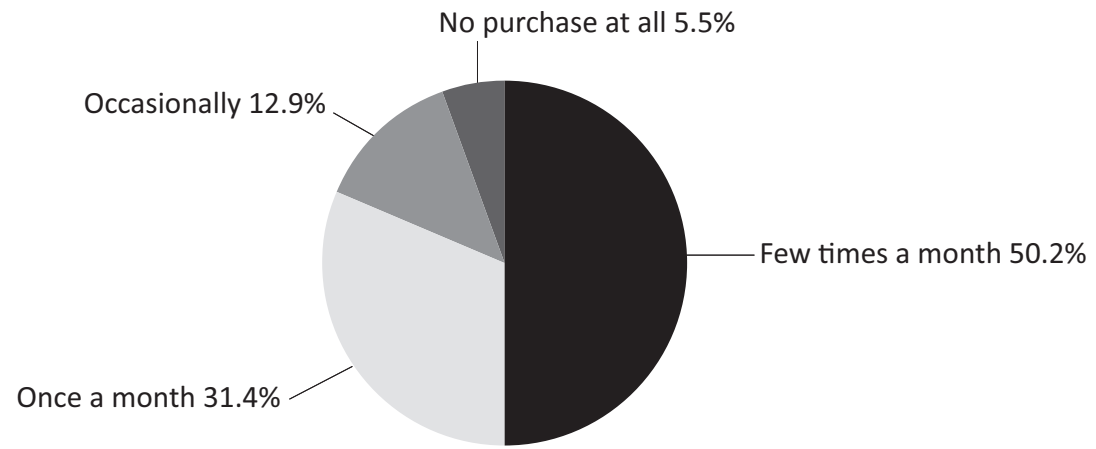

Figure 7. Frequency of purchase by respondents, traditional and regional products Source: author's study on the basis of research.

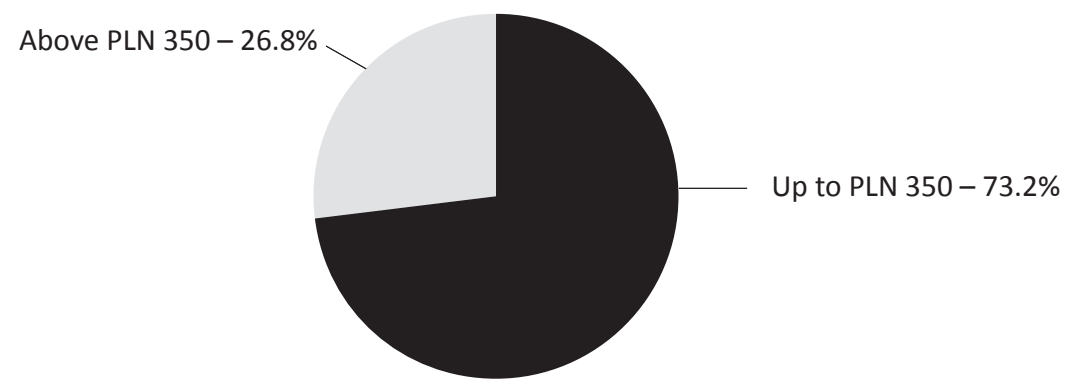

Figure 8. Monthly expense on purchase of traditional and regional products

Source: author's study on the basis of research.

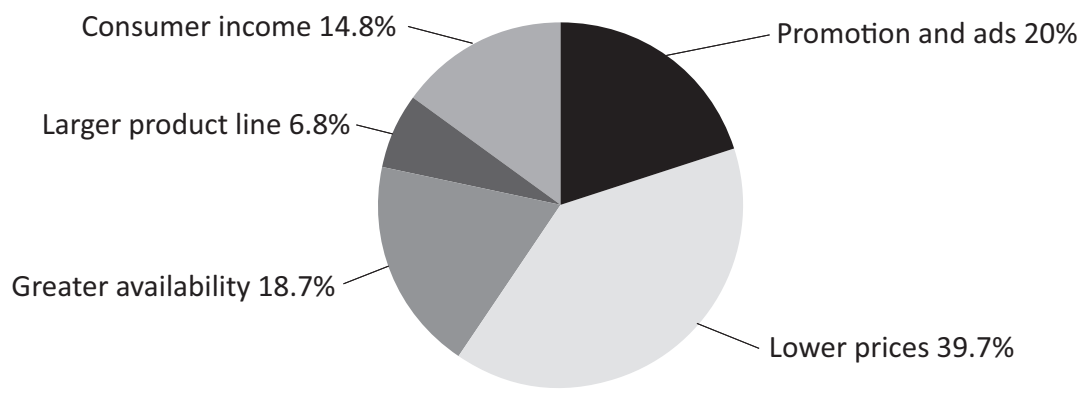

Figure 9. Factors influencing the growth in sales of traditional and regional products Source: author's study on the basis of research. 


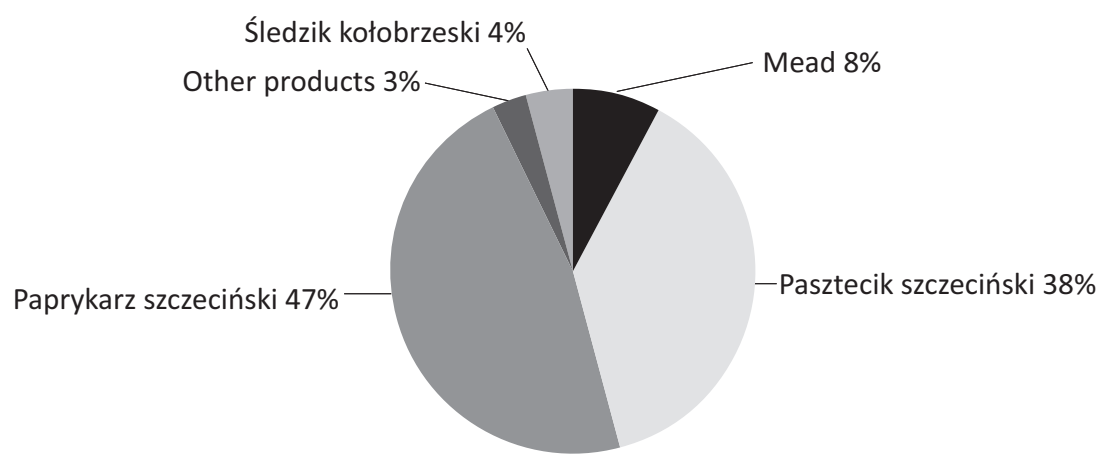

Figure 10. Traditional and regional products associated with West Pomerania by respondents Source: author's study on the basis of research.

most important factor indicated by the respondents was promotion and advertising (65 persons, 20\%) and greater availability (61 persons, 18.7\%).

In response to a question about the traditional product associated with West Pomerania (Figure 10) 47\% of the respondents chose the "paprykarz szczeciński", $38 \%$ favored "pasztecik szczeciński", $8 \%$ of those questioned chose mead, and $4 \%$ opted for the "śledzik kołobrzeski."

The next task for the respondents was to choose West Pomeranian products from a list of traditional products they were familiar with. The respondents could chose more than one answer (Table 6).

Table 6. Traditional and regional products of West Pomerania that respondents were familiar with

\begin{tabular}{|c|c|c|c|c|c|c|c|c|c|c|c|c|c|}
\hline Product & 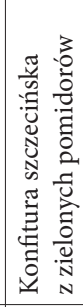 & 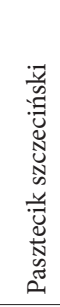 & 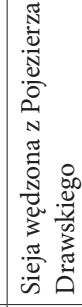 & 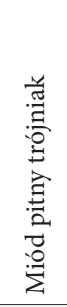 & 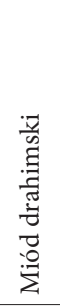 & 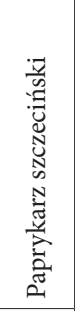 & 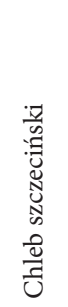 & 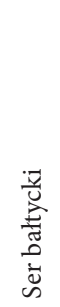 & 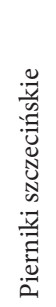 & 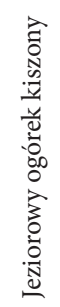 & 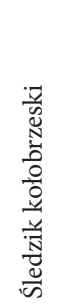 & 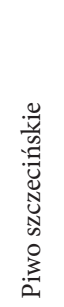 & \\
\hline $\begin{array}{l}\text { No. } \\
\text { of respon }\end{array}$ & 19 & 289 & 52 & 230 & 191 & 276 & 130 & 76 & 48 & 30 & 120 & 146 & \\
\hline
\end{tabular}

Source: author's study on the basis of research.

The most popular products associated with Szczecin are the "pasztecik szczeciński" and "paprykarz szczeciński" followed by meads and Drahim honey. 


\section{Conclusions}

Tourist motivation is an important factor to be taken into consideration while choosing a certain destination. Culture tourism plays an increasingly significant role in attracting visitors to regions with a wide and unique culinary offer. Traditional and regional products are very special features of regions, since the growing demand connected with the high quality and traditional production methods provide benefits both to producers and purchasers. The traditional and regional products associated with culinary culture speak for the diversity of the West Pomeranian culinary heritage. Their growing identification and increasing number contribute to the higher interest not only in the products themselves but in the region of their origin as well. The unique products with proven regional identity, and labelled with EU and local certificates (PDoO, PGI, TSG and TPL), would facilitate the growth and development of West Pomerania. The research showed the taste and pro-health values are key motives driving consumers to purchase the regional products.

The motivation in tourism manifests itself in the needs and the desire to extend the knowledge, learn about the customs, history and traditions of Western Pomerania. As a result, it influences the consumer choices of regional and traditional products of Western Pomerania not only due to pro-health considerations, but also the desire to try new flavors and diversify the menu. In general, the need for change and satisfaction in terms of communing with nature and tradition lies at the root of this type of consumer behavior.

The proper promotion and advertisement, as well as the availability of the products, are factors influencing the choices made by consumers. Undoubtedly, income is a decisive factor affecting the demand for regional products. Twenty-six percent of respondents said they spent above PLN 350 monthly on such purchases, whereas some $40 \%$ of the respondents said lower prices would make them buy such products more often.

In fact West Pomerania is associated with two regional products - the "pasztecik szczeciński" and "paprykarz szczeciński." Only 15\% of respondents mentioned other products when asked about the product associated with the region. It simply means it is necessary to intensify the promotion of local products not only among inhabitants of the region but in the entire country. The growing interest in such products, trends related to healthy nutrition, and decreasing interest in mass products can contribute to the higher income of local producers. 


\section{Bibliography}

European Comission (2007), European Policy for Quality of Agricultural Products.

Gaworecki W. (2003), Turystyka, Warszawa: Polskie Wydawnictwo Ekonomiczne.

Gołembski G. (ed.) (2009), Kompendium Wiedzy o Turystyce, Warszawa: PWN.

Gracz J., Sankowski T. (2001), Psychologia w Rekreacji i Turystyce, Poznań: Akademia Wychowania Fizycznego w Poznaniu.

Hofstede G., Hofstede G.J., Minkov M. (2011), Kultury i Organizacje, Warszawa: PWE.

James A., Stoner F., Freeman E., Gilbert D. (2008), Kierowanie, Warszawa: Polskie Wydawnictwo Ekonomiczne.

Jędrysiak T. (2008), Turystyka kulturowa, Warszawa: Polskie Wydawnictwo Ekonomiczne.

Kruczek Z. (2004), Współczesne tendencje w kreowaniu atrakcji turystycznych, [after:] J.R. Brent

Ritchie, M. Zins, Culture as Determinant of the Attractiveness of a Tourism Region, "Annals of Tourism Research", Vol. 5, No. 2, April/June 1978, pp. 252-267, [in:] J. Wyrzykowski, K. Klementowski (eds.), Współczesne tendencje w turystyce i rekreacji, Wrocław: AWF, p. 90.

Łazarek R. (2001), Ekonomika turystyki, Warszawa: Zakład Wydawniczy Druk Tur.

Łukaszewski W. (2000), Motywacja w najważniejszych systemach teoretycznych, [in:] J. Strelau, Psychologia. Podręcznik Akademicki, Vol. II, Gdańsk: Gdańskie Wydawnictwo Psychologiczne, pp. 427-440.

Maslow A.H. (1994) [1954], Motivation and Personality, [in:] S. Gajewski (ed.), Zachowanie się konsumenta a współczesny marketing, Łódź: Wydawnictwo Uniwersytetu Łódzkiego, p. 80.

Matlegiewicz M. (2011), Turystyka kulturowa na obszarach wiejskich województwa zachodniopomorskiego, "Journal of Agribusiness and Rural Development", No. 2(20), pp. 65-75.

Matlegiewicz M. (2014), Produkty tradycyjne i regionalne w turystyce, [in:] J. Snarski, M. Jalinik (eds.), Przedsiębiorczość w turystyce, Białystok: EkoPress, pp. 151-166.

Middleton V.T.C. (1996), Marketing w turystyce, Warszawa: Polska Agencja Promocji Turystyki.

Ministry of Agriculture and Rural Development materials, Warsaw 2006, 2010, 2012, https:// www.minrol.gov.pl [accessed: 15.07.2020].

Niezgoda A. (1999), Wpływ walorów kulturowych na motywacje podroży określonych segmentów rynku turystycznego, "Zeszyty Naukowe Wyższej Szkoły Ekonomicznej w Warszawie”, No. 1 (15), pp. 37-45.

Oznaczenia geograficzne, nazwy pochodzenia oraz gwarantowane tradycyjne specjalności w Polsce (2009), Ministerstwo Rolnictwa i Rozwoju Wsi, Warszawa: Wydawnictwo Naukowe Instytutu Technologii i Eksploatacji Państwowego Instytutu Badawczego, https://www. minrol.gov.pl, http://www.potrawyregionalne.pl [accessed: 10.07.2020].

Panasiuk A. (ed.) (2006), Ekonomika turystyki, Warszawa: PWN.

Rohrscheidt A.M. von (2008), Turystyka kulturowa: fenomen, potencjał, perspektywy, Gniezno: GWSMM Milenium.

Rudnicki L. (2010), Zachowania konsumentów na rynku turystycznym, Kraków: Proksenia. 
Sekuła Z. (2008), Motywowanie do pracy. Teorie i instrumenty, Warszawa: Polskie Wydawnictwo Ekonomiczne.

Siwiński W. (2010), Pedagogika czasu wolnego i jej związki z rekreacja, [in:] W. Siwiński, B. Pluta (eds.), Teoria i metodyka rekreacji, Poznań: Wydawnictwo Akademii Wychowania Fizycznego im. E. Piaseckiego, pp. 81-95.

Sztaba S. (ed.) (2007), Ekonomia od A do Z. Encyklopedia podręczna, Warszawa: Wydawnictwa Akademickie i Profesjonalne.

Vademecum Ochrony Produktów Regionalnych i Tradycyjnych (2004), Warszawa: Biuro Oznaczeń Geograficznych i Promocji, Ministerstwo Rolnictwa i Rozwoju Wsi.

Winiarski R., Zdebski J. (2008), Psychologia turystyki, Warszawa: Wydawnictwa Akademickie i Profesjonalne.

Zdebski J. (1996), Elementy psychologii turystyki, [in:] Z. Kruczek (ed.), Pilotaż wycieczek zagranicznych, Kraków: “Mentor”, pp. 80-94.

Zachodniopomorski ODR in Barzkowice - collected information, website, www.minrol.gov.pl [accessed: 15.07.2020].

Żywność regionalna i tradycyjna (2010), Warszawa: Ministerstwo Rolnictwa i Rozwoju Wsi. 